\title{
Editorial
}

\section{Berry important}

Are we forgetting the old ways of using berries as a source of valuable nutrients? The use of wild or garden-produced berries can certainly contribute substantially to our intake of phenols, including flavonols such as quercetin and myrecetin. The intake in my neighbouring country Finland of lingonberries (Vaccinium vitis-idaea) and bilberries (Vaccinium myrtillus) was in 1990 estimated to be around $3 \mathrm{~kg}$ per person year ${ }^{1}$. A $100 \mathrm{~g}$ portion of lingonberries every day would double average daily flavonol intake; the same amount of bilberries would provide almost another half ${ }^{1}$.

\section{Free forest berries}

In my country, Sweden, we have an ancient rule called 'The right of public access'. This means we are allowed to pick berries, flowers and mushrooms in the forest, whoever owns it. Wild berries used to make a substantial contribution to the household. Investigations from the end of the 1970s showed that during a year something like half a million tons of wild berries were produced in Swedish forests, mostly lingonberries, bilberries and cloudberries (Rubus chamaemorus).

Out of the fantastic potential of wild berry production, about $2-4 \%$ is picked for commercial use, mostly bilberries. On top of that there is household picking, which in 1995 amounted to approximately 15000 tons, while in 1977 household picking was substantially more, almost 40000 tons ${ }^{2}$. There is a huge underused potential of wild berries left in the forest. For obvious reasons, more berries are picked by inhabitants in rural areas and small towns. Currently, several projects are attempting to grow bilberries in more easily accessed areas of Sweden.

\section{Berries in households}

My grandfather did most of the berry-picking for his family of 13 in the 1930s. He took his bicycle, a sandwich pack and a thermos of coffee, and biked off (more than $20 \mathrm{~km}$ there and back) for a couple of hours, mostly to pick lingonberries. One year he picked 100 litres; a more normal yield for a summer would be 60-70 litres. These were used during the whole year. The berries were cooked, with or without sugar (with 100 litres of berries there was not enough money for sugar for the whole lot), and stored in large ceramic jars, kept in cool storage. The most common dessert was lingonberry sauce with milk, and lingonberries were also served with porridge and pancakes and as a condiment with meat or meatballs.

This berry-picking was driven by my grandfather's wish to spend time in the forest, and also by his strong wish to support his family. He worked for the family most days of the week, and also used the hours before dark to pick berries. Garden berries were of great importance for Swedish households in the era before and after the Second World War. Raspberries, strawberries, gooseberries, blackand redcurrants, and cherries, were grown in most gardens and used as desserts and condiments. A household with a garden could produce tens of litres of each berry, so these made a significant contribution to dietary and nutritional intake as well as to the economy of the households.

\section{Berries and health}

Research on wild berries and their importance for health is ongoing in Finland ${ }^{3,4}$. Several new findings report the importance of phenolic components found in berries for selective inhibition of pathogenic bacteria in the human gut. Animal research is investigating possible use of berries to prevent cognitive disorders in old age $^{5}$. There is also a substantial interest in these berries as functional foods.

This year, bilberries are especially popular in Sweden. Recipes containing bilberries are provided in most of the glossy weekly magazines as well as in daily newspapers. Let us hope that other wild berries and the berry-picking custom, as a way to be physically active and to experience wildlife, will also increase in importance.

Our grandparents knew how to stretch the pay cheque. Nothing went to waste, and free resources were certainly used. Previously the relatively low content of vitamin C in these berries made the public - as well as nutritionists lose interest in the fruits of the forest. Now we know more about the importance of other compounds than vitamins and should value these free natural resources more.

In the mean time, you are all welcome to Sweden to pick berries next year. This year probably around 250000 tons of wild berries went to waste, since we Swedes are too lazy to pick them.

Agneta Yngve

Editor-in-Chief 


\section{References}

1 Hakkinen SH, Karenlampi SO, Heinonen IM, Mykkanen HM, Torronen AR. Content of the flavonols quercetin, myricetin, and kaempferol in 25 edible berries. Journal of Agricultural and Food Chemistry 1999; 47(6): 2274-9.

2 SCB. Environmental accounts; Forest accounts - physical data. Örebro: Statistics Sweden, 1999.

3 Heinonen M. Antioxidant activity and antimicrobial effect of berry phenolics - a Finnish perspective. Molecular Nutrition \& Food Research 2007; 51(6): 684-91.
4 Puupponen-Pimia R, Nohynek L, Hartmann-Schmidlin S, Kahkonen M, Heinonen M, Maatta-Riihinen K, et al. Berry phenolics selectively inhibit the growth of intestinal pathogens. Journal of Applied Microbiology 2005; 98(4): 991-1000.

5 Joseph JA, Shukitt-Hale B, Lau FC. Fruit polyphenols and their effects on neuronal signaling and behavior in senescence. Annals of the New York Academy of Sciences 2007; 1100: $470-85$. 